\title{
A NOTE ON JEROME'S HOMILY ON THE RICH MAN AND LAZARUS ${ }^{1}$
}

A passage in Jerome's homily on the story of the rich man and Lazarus (Luke $16: 19-31$ ), where the author is commenting on vv. 22-23 factum est autem ut moreretur mendicus et portaretur ab angelis in sinum Abrahae; mortuus est autem et dives et sepultus est. in inferno elevans oculos suos, cum esset in tormentis, videbat Abraham a longe et Lazarum in sinu eius, ${ }^{2}$ reads thus:

videbat Abraham a longe: respiciebat, ut tantummodo torqueretur. et Lazarum in sinu eius. paradisus pauperis, sinus erat Abrahae. Abraham a longe, et Lazarum in sinu eius. dicat mihi aliquis: in inferno est paradisus? ego hac dico, quia sinus Abrahae paradisi veritas est: sed et sancti sinum paradisum fateor. (p. 510 ll. $91-96)^{3}$

The first part of the passage is easily translated:

'He saw Abraham far off': he looked, only to be tormented. 'And Lazarus in his bosom.' Abraham's bosom was the poor man's paradise. 'Abraham far off, and Lazarus in his bosom.' Someone may say to me: is paradise in hell?

The final sentence will be discussed below.

This homily is an important text for our knowledge of Jerome's eschatological views, which were investigated in detail, from a Roman Catholic viewpoint, by J. P. O'Connell in 1948.

1 References to ancient texts follow in almost all cases the new index to the Thesaurus linguae Latinae ( $T L L$ ) (Leipzig, 1990). CCSL m Corpus Christianorum, series Latina. References to periodicals follow the system of $L$ 'Année philologique.

I should like to thank Emily Kearns for practical assistance with the research for this article, and Marica Frank and ' JTS' anonymous referee for helpful suggestions.

2 The text is that of the Vulgate in the edition of R. Weber (Stuttgart, $1975^{2}$ ), with my punctuation. The text cited by Jerome in the homily differs from this only in minor respects.

${ }_{3}$ The work is cited according to CCSL 78 pp. 507-16, which reproduces the text of G. Morin, Sancti Hieronymi presbyteri tractatus sive homiliae in Psalmos, in Marci evangelium aliaque varia argumenta (Anecdota Maredsolana, 3.2; Maredsous and Oxford, 1897). Morin's text, based on four MSS and the text of the homily in Erasmus' Latin edition of John Chrysostom, to whom the homily was formerly attributed, leaves much to be desired, but remains the only critical text. In respect of the passage quoted, there is nothing to be said for any of the variant readings which Morin reports.

4 Translations are my own, though I have had regard to the version of $M$. $L$. Ewald, The Homilies of Saint Jerome: Volume 2 (Homilies 60-q6) (The Fathers of the Church, 57; Washington, DC, 1966), 200-11.

3 J. P. O'Connell, The Eschatology of Saint Yerome (Pontificia Facultas Theologica Seminarii Sanctae Mariae ad Lacum, Dissertationes ad lauream, 16; Mundelein, Illinois, 1948).

- Oxford Univerdity Preae 1997

Uournal of Theoloylcal studies, NB, Vol. 48, PT, 2, October 1997] 
O'Connell showed that, though the General Judgement was central to Jerome's eschatological thought, he held that the righteous obtained their reward immediately after death. ${ }^{6}$ The death and resurrection of Christ were instrumental in achieving this, for it was at his resurrection that paradise ${ }^{7}$ was opened. A natural corollary was the view that until Christ's resurrection even the patriarchs were excluded from paradise; along with the souls of all the dead, they dwelt in infernus, 'hell' in the broad sense, from which they were released by Christ after his death on the cross. The position is made quite clear later in the homily:

simulque considerandum, quod Abraham apud inferos erat: necdum enim $X$ pistus resurrexerat, qui illum in paradisum duceret. antequam Xpistus moreretur, nemo in paradisum conscenderat [nisi latro]. ${ }^{8}$ romphaea illa flammea et vertigo illa claudebat paradisum [cf. Gen. 3:24]: non poterat aliquis intrare in paradisum, quem Xpistus clauserat. Latro primus intravit cum Xpisto. (p. 5I 5 11. 269-75)

It should also be noted that Abraham was among those in hell; for Christ had not yet risen to lead him into paradise. Before the death of Christ, no one had ascended into paradise. That flaming, whirling sword was keeping paradise shut; no one could enter paradise, which Christ had closed. The robber was the first to enter with Christ.

Abraham necdum erat in paradiso, quia necdum Xpistus intraverat cum latrone. venit Xpistus, et passus est: et multa corpora sanctorum resurrexerunt, et visa sunt in sancta civitate. crux $X$ pisti clavis paradisi est, crux $X$ pisti aperuit paradisum. non vobis dixit quod 'regnum caelorum vim patitur et violenti diripiunt illud' [Matt. $11: 12$ ]? qui in cruce est, non vim facit? nihil medium est: crux et statim paradisus... (pp. 515-16 11. 293-300)

Abraham was not yet in paradise, because Christ had not yet entered

6 O'Connell (n. 5), 73-101, esp. 87-92; though issue can be taken with some of what he says in this chapter, the main point is firmly established. Jerome's view in essentials was standard from the fourth century at least; for a helpful summary of opinions see J. N. D. Kelly, Early Christian Doctrines (London, 1977), 482-83 (who, however, I believe misinterprets Jer. in Is. 6.13.6-9), and, for the views of earlier writers, C. E. Hill, Regmum caelorum: Patterns of Future Hope in Early Christianity (Oxford, 1992).

7 Or heaven (caelum, regmum caelorum, etc.): except where paradisus specifically denotes the Garden of Eden, Jerome normally treats the terms as synonymous and interchangeable; see e.g. pp. 515-16 11. 296-300, quoted below, in Is. 9.30.9 11. 20-22, tract. in psalm. II p. 409 ll. 147-50, tract. in Marc. p. 461 11. 58-70 (CCSL 78), in eccles. $3.1811 .300-303$.

nisi latro= 'except the robber' makes no sense here, and it is hard to see how nisi can be construed in any other way. Ewald (n. 4), 209, translates 'not even the robber', but the observation would have little point even if the Latin could bear this meaning. The anonymous referee rightly presses me to delete.

- flamma in CCSL 78 is a simple misprint. 
with the robber. Christ came, and suffered; and the bodies of many saints arose, and were seen in the holy city. The cross of Christ is the key to paradise, the cross of Christ opened paradise. Did he not say to you, 'The kingdom of heaven suffers assault, and violent hands are laid upon it' ? $^{10}$ Does not the one on the cross cause the violence? There is nothing in between: the cross and at once paradise.

Other texts in Jerome confirm the situation. ${ }^{11}$

In the light of this it becomes absolutely clear that the text of our passage cannot stand. Following his comment that 'Abraham's bosom was the poor man's paradise', Jerome presents an objection by an imaginary interlocutor: 'Is paradise in hell?'. Plainly paradise is not in hell, and Jerome cannot have replied: 'I say this, that Abraham's bosom is the true paradise; but I admit the holy man's bosom to be paradise too.'12 There is a clear contrast between true paradise (paradisi veritas), which was yet to be attained, and the approximation to paradise, which was Abraham's bosom in infernus. To the imaginary question Jerome must have replied that Abraham's bosom was not the true paradise; but, in a manner of speaking, it too could be regarded as paradise. The rich man and Lazarus are both in infernus, but in different parts of it. ${ }^{13}$ The rich man experiences torment, prefiguring the ultimate torment which will follow the Judgement, ${ }^{14}$ while Lazarus waits in Abraham's bosom, a place of refreshment, ${ }^{15}$ the closest thing to paradise.

To propose that a negative particle has dropped out of a text is apt to raise eyebrows. ${ }^{16}$ But this is evidently what has happened

10 The violence of which Jerome speaks is to be understood as that of the resolute, pressing into the kingdom of heaven; cf. e.g. epist. 22.40.5, 60.3.4, in Matth. I1.12.

1 See e.g. epist. 39.4.2-5, 60.3, 129.2.1, in eccles. 3.18 11. 294-303, tract. in Marc. pp. 461-62 11. 58-76 (CCSL 78), tract. in psalm. I p. 207 11. 179-86; also O'Connell (n. 5), r 33-37.

12 The alternative rendering of Ewald (n. 4), 203, makes just as little sense: 'I gay this, that Abraham's bosom is true Paradise, but I also grant that the bosom of a holy man is Paradise.'

${ }_{13}$ Between them is chaos magrum, a great gulf which cannot be crossed (Luke 16:26).

14 See pp. 514-15 11. 247-68.

15 See p. 5 I4 l. 251 , and cf. epist. 39.4.2, 60.3.2; the division of infermus into a place of punishment and a place of refreshment is found too at in Os. 13.14-15 il. 3r3-r 5 .

${ }_{16}$ I have raised them myself in the case of another passage in Jerome; see my 'Notes on the Text of Jerome, Letters $I$ and 107', $C Q 37$ (1987), 487-97, at 489 n. 17. 
here. ${ }^{17}$ Jerome will have said, or intended to say, sinus Abrahae paradisi veritas <non> est, or something similar. The error is explained all the more easily in the case of a text which by general agreement was taken down from Jerome's oral delivery by members of his monastic congregation at Bethlehem and not corrected by him. ${ }^{18}$ 'Manche befremdende Einzelheit mag überhaupt nicht auf des Redners, sondern auf der Nachschreiber Rechnung zu setzen sein', wrote Bardenhewer of the homilies in general, ${ }^{19}$ and a careful reading of the text reveals many corruptions or probable corruptions.

J. H. D. SCOURFIELD

17 As in three MSS at another place later in the homily (p. 513 l. 204): see Morin's apparatus criticus, where (as I discover by autopsy) $O$ should be added to $F L$.

${ }^{18}$ See e.g. G. Grutzmacher, Hieronymus: eine biographische Studie zur alten Kirchengeschichte 3 vols. (Leipzig and Berlin, 1901-1908), 1.16, 3.142; O. Bardenhewer, Geschichte der altkirchlichen Literatur 5 vols. (Freiburg im Breisgau, 1902-32 (vols. 1-2, 1913-14²)), 3 (1912), 642; F. Cavallera, Saint féóme: sa vie et son oetvre 2 vols. (Spicilegium sacrum Lovaniense, 1-2; Louvain, 1922), I.185-86, esp. I85 n. 2; B. Altaner, Patrology (Engl. tr. of 5th German edn., New York, 1960), 471; J. N. D. Kelly, Yerome: His Life, Wntings, and Controversies (London, 1975), 136-37 (all referring to the homilies collectively).

19 See n. 18 above. 